\title{
Modifiable risk factors and multidisciplinary approaches
}

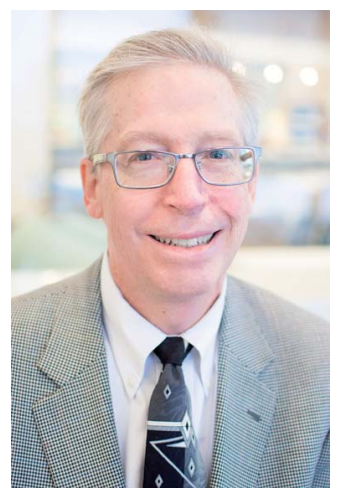

I $\mathrm{t}$ is increasingly evident that brain disease cannot be diagnosed, treated, andperhaps most importantly_prevented without consideration of a person's overall health. In this issue of Neurology ${ }^{\circledR}$ Clinical Practice, Filley (p. 193) and Breitner and Galasko in an accompanying editorial (p. 190) discuss Alzheimer disease in the context of modifiable risk factors, a view with "important implications for medical care and health policy." The article by Wright and Flores (p. 201) on vascular contributions to cognitive impairment adds further nuance to this discussion. Rumbaugh and Tyor (p. 224) outline recent advances HIV-associated neurocognitive disorders, another important cause of cognitive disability.

In our Statistics in Clinical Practice section, Wang and Cutter (p. 253) tackle the thorny topic of how to ascertain whether one medication or procedure is better than, equivalent to, or inferior to, an alternative choice. Lonnquist et al. (p. 241) discuss the ethics and logistics of providing neurologic care in criminal systems and state mental hospitals. An accompanying editorial by Satya-Murti and Lockhart (p. 188) elaborates on navigation through these unique practice settings. Liberman et al. (p. 247) describe a potential unintended consequence of rapid thrombolysis - increased administration of IV tissue plasminogen activator to "stoke mimics," nonvascular conditions that simulate stroke.

We hope you enjoy and learn from these stimulating articles as much as we have. American Academy of Neurology members enjoy Full Access to every issue on the $\mathrm{iPad}^{\circledR}$. If you are not yet a member, download the app and GET THE LATEST ISSUE FREE! (Go to http://bit.ly/NCPapp for details.)
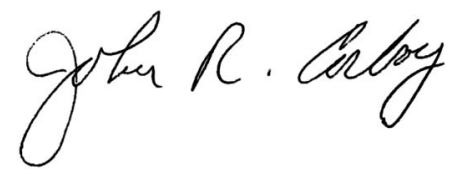

John R. Corboy, MD, FAAN 


\title{
Neurology ${ }^{\circ}$ Clinical Practice
}

\author{
Modifiable risk factors and multidisciplinary approaches \\ Neurol Clin Pract 2015;5;183 \\ DOI 10.1212/CPJ.0000000000000147
}

This information is current as of June 8, 2015

\section{Updated Information \& Services}

Permissions \& Licensing

Reprints including high resolution figures, can be found at:

http://cp.neurology.org/content/5/3/183.full.html

Information about reproducing this article in parts (figures,tables) or in its entirety can be found online at:

http://cp.neurology.org/misc/about.xhtml\#permissions

Information about ordering reprints can be found online: http://cp.neurology.org/misc/addir.xhtml\#reprintsus

Neurol Clin Pract is an official journal of the American Academy of Neurology. Published continuously since 2011, it is now a bimonthly with 6 issues per year. Copyright ( $\odot 2015$ American Academy of Neurology. All rights reserved. Print ISSN: 2163-0402. Online ISSN: 2163-0933.

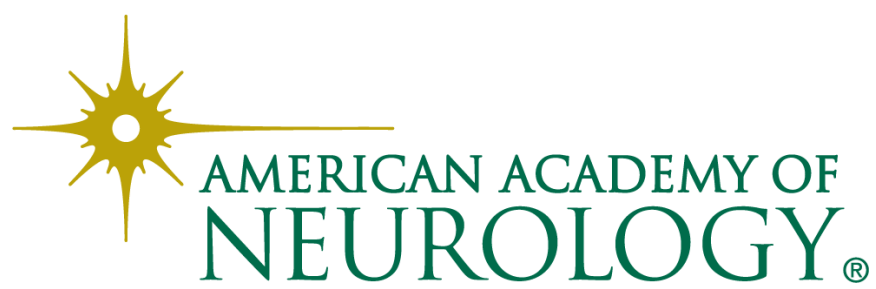

